\title{
Preliminary Report on the 22 December 2003, M 6.5 San Simeon, California Earthquake
}

\author{
Jeanne L. Hardebeck', John Boatwright ${ }^{1}$, Douglas Dreger², Rakesh \\ Goel $^{3}$, Vladimir Graizer ${ }^{4}$, Kenneth Hudnut ${ }^{5}$ Chen $\mathrm{Ji}^{6}$, Lucile Jones ${ }^{5}$, \\ John Langbein ${ }^{1}$, Jian Lin ${ }^{7}$, Evelyn Roeloffs ${ }^{8}$, Robert Simpson ${ }^{1}$, Keith \\ Stark $^{5}$, Ross Stein ${ }^{1}$, and John C. Tinsley ${ }^{1}$
}

\section{INTRODUCTION}

The $M_{w} 6.5$ San Simeon earthquake struck the central California coast on 22 December 2003 at 19:15:56 UTC (11:15:56 AM local time.) The epicenter was located $11 \mathrm{~km}$ northeast of the town of San Simeon, and $39 \mathrm{~km}$ west-northwest of Paso Robles (Figure 1), as reported by the California Integrated Seismic Network (CISN, the California region of the Advanced National Seismic System [ANSS]). The mainshock nucleated at $35.702^{\circ} \mathrm{N}, 121.108^{\circ} \mathrm{W}$ and a depth of $7.1 \mathrm{~km}$, and the rupture propagated unilaterally to the southeast. The strong directivity of the rupture resulted in a concentration of damage and aftershock activity to the southeast of the hypocenter. The worst earthquake damage occurred in Paso Robles, where two people died in the collapse of an unreinforced masonry building. The accurate and rapid earthquake information provided in near real-time by CISN/ ANSS to the Governor's Office of Emergency Services made it possible to focus emergency response in the source area, although the earthquake was felt from San Francisco to Los Angeles.

The San Simeon earthquake occurred on a reverse fault striking northwest and most likely dipping to the northeast. Although motion along the Pacific-North America plate boundary in California is dominantly strike-slip, there is a small compressional component through central California. Repeated thrust earthquakes such as the San Simeon event accommodate this compression and build the Coast Ranges. Other recent thrust earthquakes in central California include the 1983 Coalinga (M 6.4) and the 1985 Kettleman Hills (M 6.0) earthquakes. Prior earthquakes in the vicinity of the San Simeon event include a M 5-6 earthquake in 1853, a

\footnotetext{
1. U.S. Geological Survey, Menlo Park

2. University of California at Berkeley

3. California Polytechnic State University at San Luis Obispo

4. California Geological Survey

5. U.S. Geological Survey, Pasadena

6. California Institute of Technology

7. Woods Hole Oceanographic Institution

8. U.S. Geological Survey, Vancouver
}

M 5.7 earthquake in 1906, and the $M_{L} 6.2$ Bryson earthquake of 1952 (Figure 1) (McLaren and Savage, 2001.)

The San Simeon earthquake occurred on a previously unknown blind thrust fault. No surface rupture associated with the earthquake has been identified. A number of roads, including State Highway 46, buckled due to the earthquake, but this deformation appears mainly to be failure of road fill due to ground shaking and not the result of tectonic surface rupture. Extrapolation of the fault plane to the surface would roughly align with the surface trace of the Oceanic Fault, but this is thought to be a vertical strike-slip fault.

Two models for the kinematics of the region have previously been proposed. The first is a fault-propagation fold model developed by Namson and Davis (1990) for the Santa Lucia mountains $-30 \mathrm{~km}$ to the southeast of the San Simeon sequence. The mainshock geometry is similar to, although more steeply dipping than, the main blind thrust of this model, implying that this model may be applicable to the San Simeon region as well. The second is the model of McLaren and Savage (2001), in which the region is dominated by strike-slip faulting with shortening on high-angle reverse faults. This model also may be applicable, although the dip of the San Simeon mainshock is shallower than predicted.

The San Simeon earthquake was followed by a vigorous aftershock sequence, with 165 events above M 3 reported by CISN within the first week of the mainshock. Although the event triggered many aftershocks, it did not significantly impact the seismicity rates of other nearby faults such as the San Andreas Fault and the San Simeon-Hosgri fault zone. The only triggered seismicity seems to be a few small events within the mainshock coda at the Geysers geothermal area, north of San Francisco. The San Simeon earthquake did, however, trigger shallow creep on the San Andreas Fault at Parkfield and hydrologic changes in hot springs in Paso Robles.

\section{MAINSHOCK SOURCE MODELING}

The mainshock was first modeled as a spatial and temporal point source, using regional data from CISN. The seismic moment tensor and the best source depth were determined by 


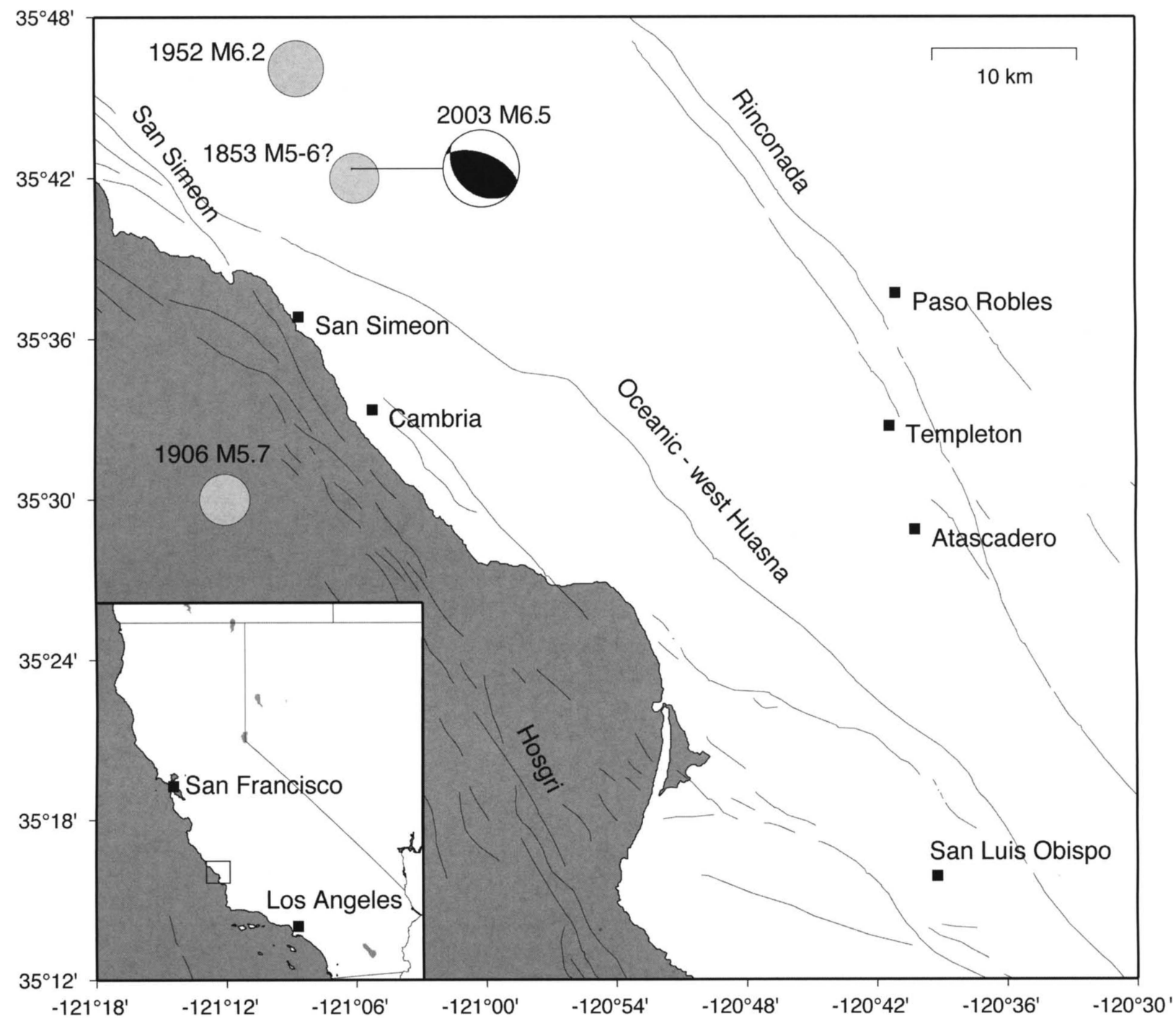

$\Delta$ Figure 1. A map of the Central California coast near the hypocenter of the 2003 M 6.5 San Simeon earthquake. Lines indicate mapped fault traces from Jennings (1975). The moment-tensor solution for the 2003 earthquake is shown, along with probable locations of prior earthquakes from McLaren and Savage (2001).

fitting seismic waveform data from the Berkeley Digital Seismic Network (BDSN/CISN). The focal parameters for the mainshock were found to be strike $290^{\circ}$, dip $58^{\circ}$, rake $78^{\circ}$ and depth $8 \mathrm{~km}$ with a scalar seismic moment of $6.0 \times$ $10^{25}$ dyne-cm. The strike of the fault is aligned WNW-ESE with the predominant trend of regional structure (Figure 1). The $P$-wave first-motion solution found by the Northern California Seismic Network (NCSN/CISN) was strike $297^{\circ}$, dip $56^{\circ}$, rake $97^{\circ}$, very similar to the moment-tensor solution.

A finite source model was also determined from the regional BDSN/CISN stations. Broadband, three-component, displacement waveforms from six stations were inverted using the method of Dreger and Kaverina (2000) to determine the distribution of fault slip. The finite-fault modeling assumes a planar fault striking $290^{\circ}$ and dipping $58^{\circ}$ to the northeast. Although there is a slight preference for the northeast-dipping plane, the difference in fit using either of the moment-tensor nodal planes is not significant. The aftershock distribution suggests the northeast-dipping plane, discussed below (Figure 2). The rake is held fixed at the moment tensor value of $78^{\circ}$. The fault dimensions are $44 \mathrm{~km}$ along strike and $22 \mathrm{~km}$ along dip, with $2 \mathrm{~km}$ by $2 \mathrm{~km}$ subfaults. The hypocenter is located at a depth of $8 \mathrm{~km}$ in the center of the fault. The fault dimensions are oversized for an $M_{w} 6.5$ event to allow the data to determine the direction of the rupture. Slip positivity and derivative minimization smoothing (e.g., Hartzell and Heaton, 1983; Dreger and Kaverina, 2000) were employed to stabilize the inversions.

Assuming a single slip time window, the slip rise time and rupture velocity were found by performing inversions over a range of values. The data are rich in low frequencies, and we found that a rise time of 3 seconds and a rupture velocity of $2.1 \mathrm{~km} / \mathrm{s}$ best fit the data. With this simplified initial fault model the slip was found to extend to the southeast approxi- 

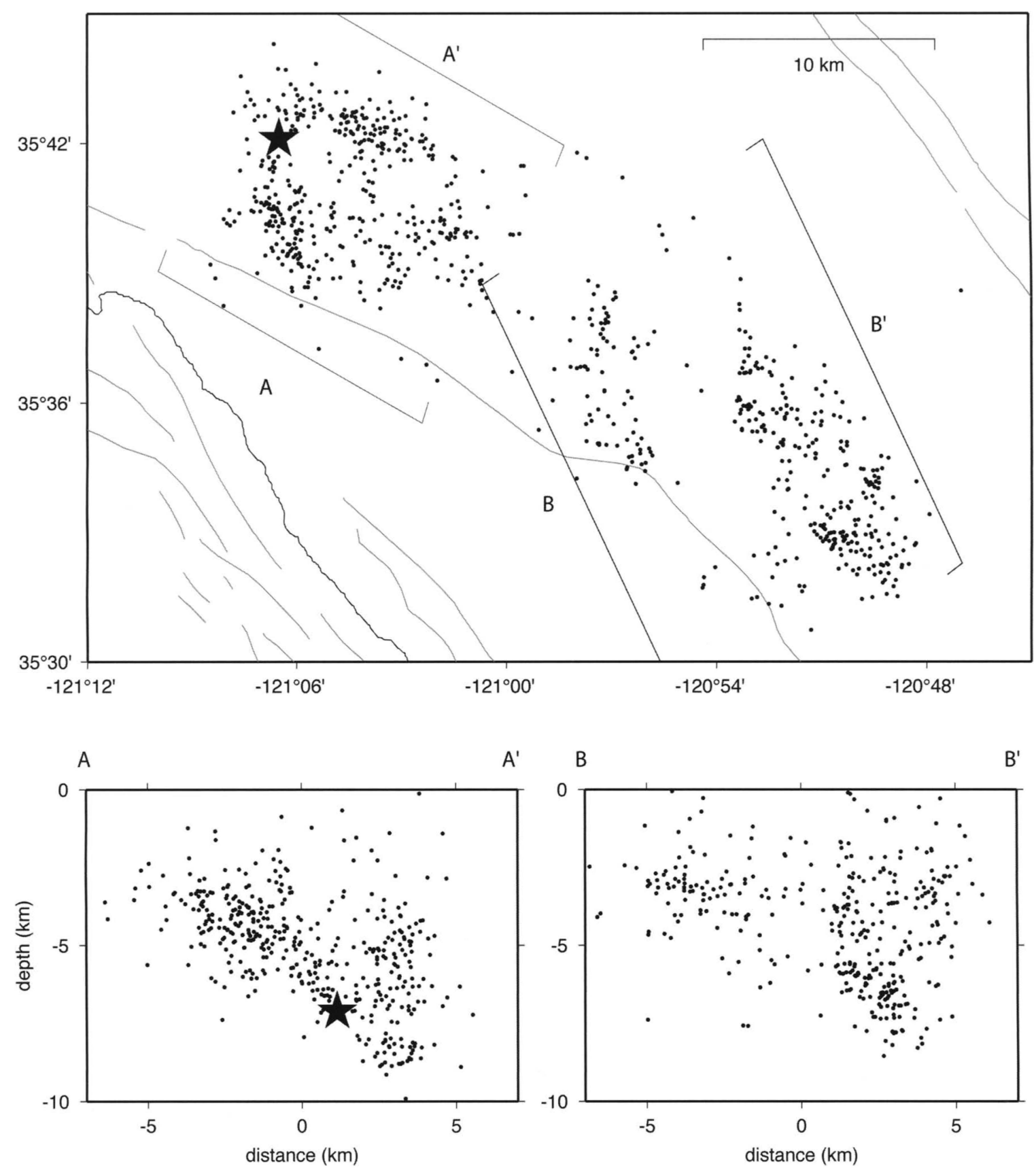

A Figure 2. Double-difference event locations for 783 aftershocks occurring within a week of the San Simeon mainshock, shown in map view and crosssection. The star denotes the mainshock hypocenter.

mately $20 \mathrm{~km}$ and primarily updip from the hypocenter (Figure 3). The shallow nature of the slip is consistent with the shallow nature of the aftershocks, which are generally shallower than the mainshock's $8 \mathrm{~km}$ depth (Figure 2). The peak and average slip were found to be $131 \mathrm{~cm}$ and $33 \mathrm{~cm}$. The scalar seismic moment was found to be $5.7 \times 10^{25}$ dyne-cm, consistent with the long-period moment-tensor result. The average slip and area of the main slip patch yield a static stress drop of 12.6 bars. With this simplified fault model, reasonably good fits to the data were obtained (Figure 3 ).
A second finite slip model for the 2003 San Simeon earthquake was developed from teleseismic $P$ waveforms, obtained from the IRIS/DMC Data Center (Figure 4). Two fault planes were first constructed using the NCSN/CISN hypocenter location and the CMT solution of SCSN/CISN and then modified to achieve a better waveform fit. A finite fault inversion using the method of Ji et al. (2002) indicates that both nodal planes could fit the data well but that the northeast-dipping plane (strike $307^{\circ}$, dip $50^{\circ}$ ) fits slightly better. Modeling with either possible fault plane clearly shows that rupture propagated southeastward. The southeast direc- 


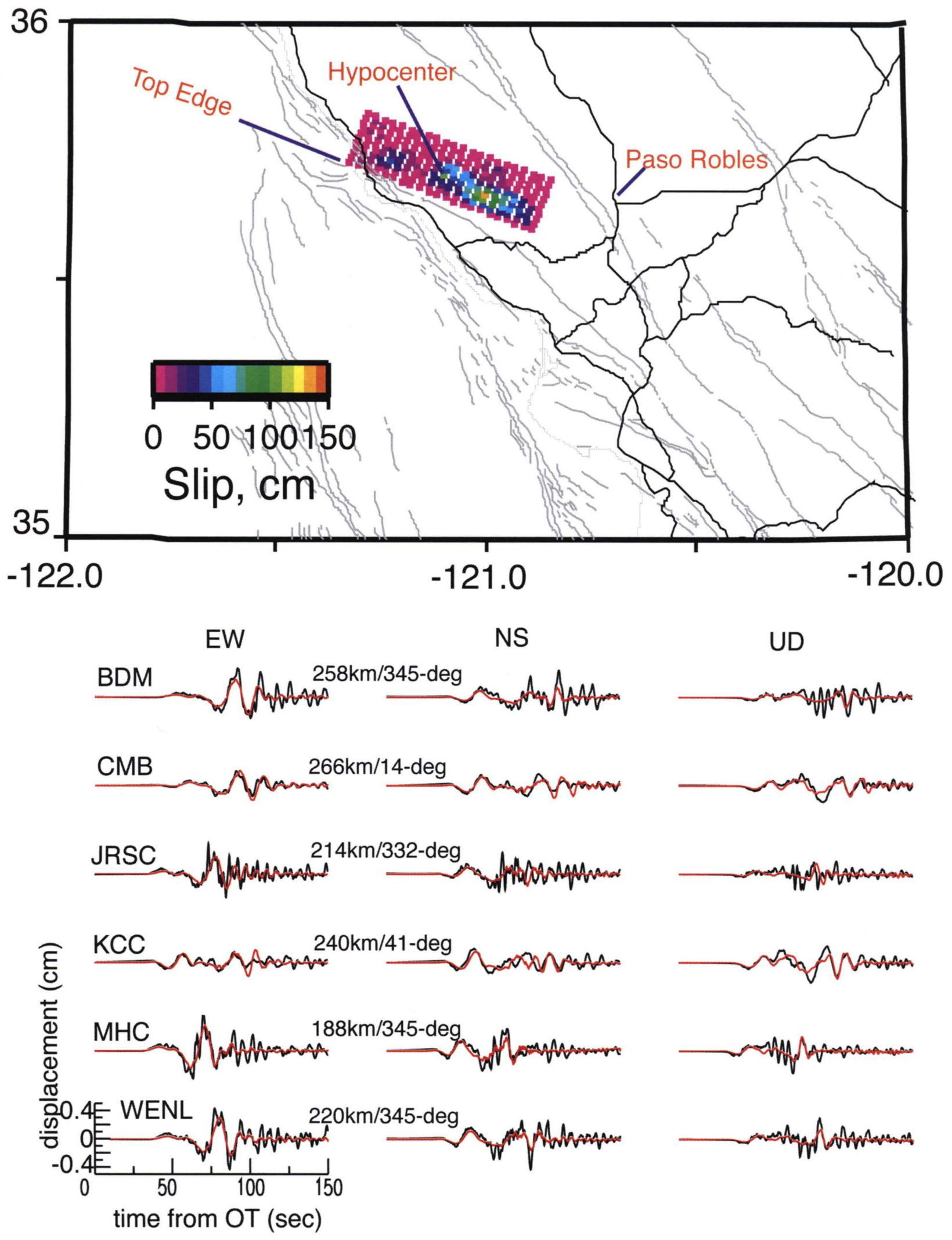

A Figure 3. Mainshock slip distribution from BDSN/CISN data. Top: Map showing faults (gray), highways (thick black lines), and the surface projection of fault slip. The slip is located updip and to the southeast of the hypocenter. The fault strikes $290^{\circ}$ and dips $58^{\circ}$ to the northeast. Bottom: Comparison of broadband $(0.01-5.0 \mathrm{~Hz}$ ) observed (black) and synthetic (red) displacement waveforms at sites used to obtain the slip model shown in Figure 3 . The fits are good, with a combined variance reduction of $45 \%$. The distance and azimuth with respect to the epicenter to each of the stations is listed. 

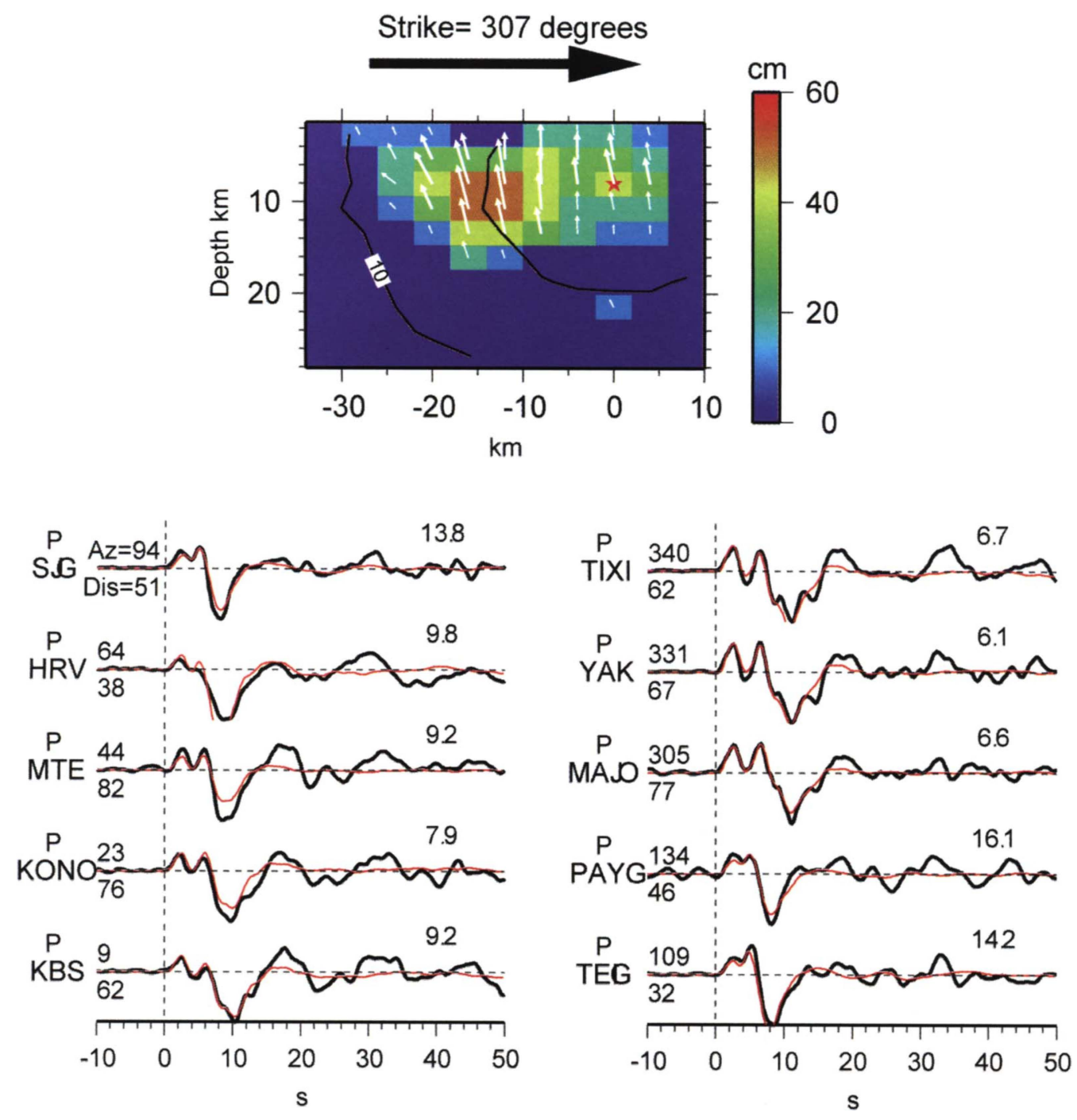

A Figure 4. Top: Cross-section of a teleseismic slip model for the 2003 San Simeon earthquake. The color shows the slip amplitudes, and white arrows indicate the slip direction. Note that the major thrust motion occurs southeast of the hypocenter, indicated by a red star. Bottom: Comparison of teleseismic $P$ waveforms (black lines) and synthetic seismograms (red lines). The number at end of each trace is the peak displacement (micrometer) of the data and has been used to normalize both the record and the corresponding synthetic seismogram. The number below the trace is the epicentral distance, and above it is the azimuth.

tivity can be seen by comparing the waveforms at stations PAYG and MAJO: The waveform at PAYG is much more compact than that at MAJO. Since the ray path to PAYG is roughly southeast, and that to MAJO is roughly northwest, only southeast propagation could explain the difference. The slip is concentrated around $-10 \mathrm{~km}$ depth, with a peak of $-50 \mathrm{~cm}$, and is nearly pure dip-slip. The total scalar moment is $5.2 \times 10^{25}$ dyne-cm $\left(M_{w} 6.4\right)$ using a layered rigidity model converted from CRUST 2.0 (Bassin et al., 2000) at the hypocenter.

Both finite-fault models described above produce similar, fairly simple slip patterns. The teleseismic model has lower peak slip but larger downdip extension. The majority of slip takes place on a small area near the hypocenter and a main area $-15 \mathrm{~km}$ to the southeast. Neither model contains much slip at the surface, suggesting a blind thrust fault. Both finite- fault models indicate that this earthquake had a significant component of directivity to the southeast, providing an explanation for the relatively high levels of damage in Paso Robles and the high peak acceleration recorded in Templeton, both located to the southeast of the epicenter.

\section{STRONG MOTION, ShakeMap, AND COMMUNITY INTERNET INTENSITIES}

The mainshock was recorded by three strong-motion instruments in the near-source region. All three of these instruments are operated by the California Geological Survey (CGS) under the CSMIP and CISN programs. The distribution of peak motions indicates that the ground motion was strongly conditioned by the mainshock rupture directivity to the southeast (Figure 5). The instrument near Cambria, only 
CISN Rapid Instrumental Intensity Map Epicenter: $11 \mathrm{~km}$ NE of San Simeon, CA Mon Dec 22, 2003 11:15:56 AM PST M 6.5 N35.71 W121.10 Depth: 7.6km ID:40148755

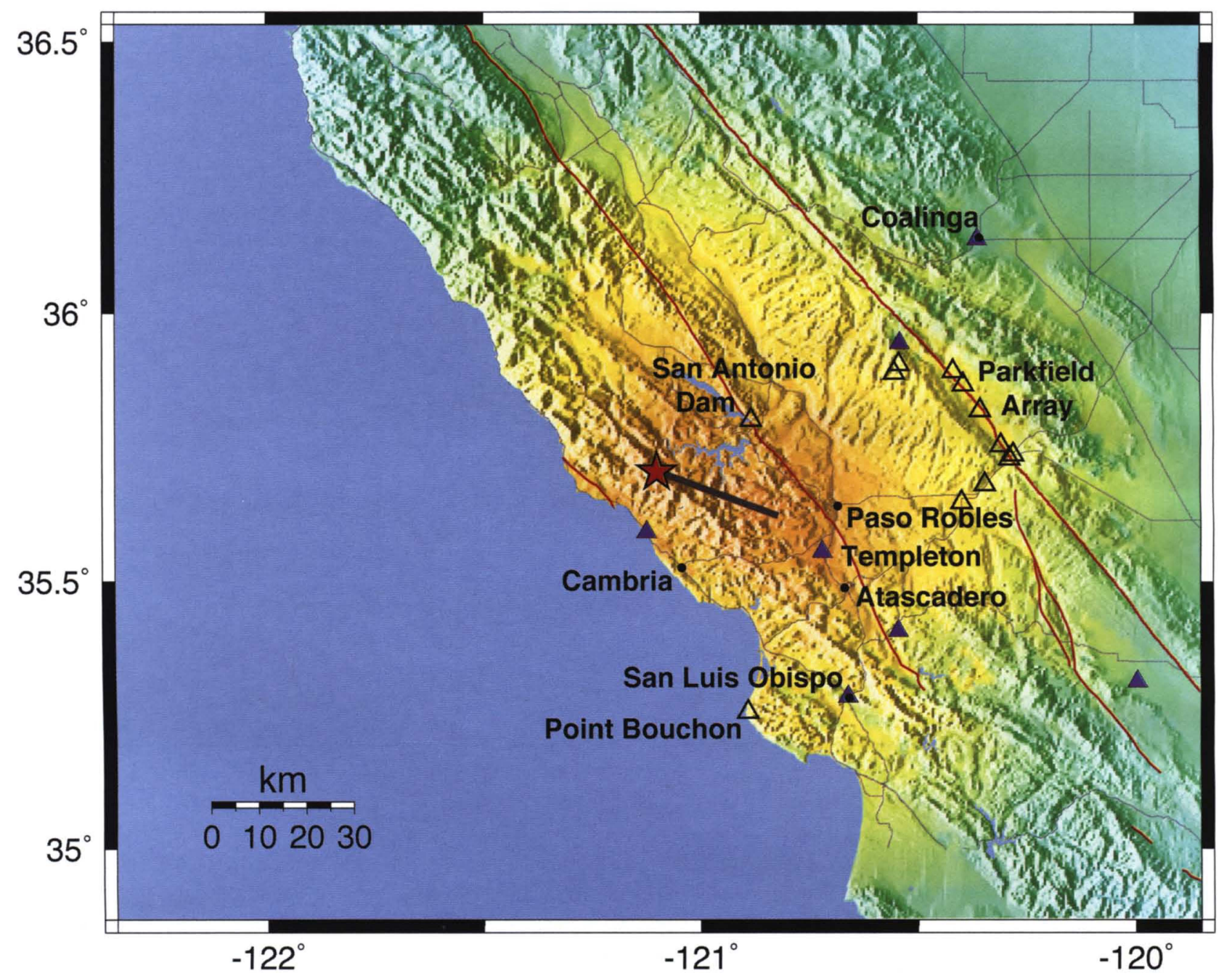

PROCESSED: Tue Dec 23, 2003 06:02:34 PM PST,

\begin{tabular}{|c|c|c|c|c|c|c|c|c|c|}
\hline $\begin{array}{c}\text { PERCEIVED } \\
\text { SHAKING }\end{array}$ & Not felt & Weak & Light & Moderate & Strong & Very strong & Severe & Violent & Extreme \\
\hline $\begin{array}{c}\text { POTENTIAL } \\
\text { DAMAGE }\end{array}$ & none & none & none & Very light & Light & Moderate & Moderate/Heavy & Heavy & Very Heavy \\
\hline PEAK ACC.(\%g) & $<.17$ & $\mathbf{. 1 7 - 1 . 4}$ & $\mathbf{1 . 4 - 3 . 9}$ & $\mathbf{3 . 9 - 9 . 2}$ & $\mathbf{9 . 2 - 1 8}$ & $18-34$ & $34-65$ & $65-124$ & $>124$ \\
\hline PEAK VEL.(cm/s) & $<0.1$ & $0.1-1.1$ & $1.1-3.4$ & $3.4-8.1$ & $8.1-16$ & $\mathbf{1 6 - 3 1}$ & $\mathbf{3 1 - 6 0}$ & $\mathbf{6 0 - 1 1 6}$ & $>\mathbf{1 1 6}$ \\
\hline $\begin{array}{c}\text { INSTRUMENTAL } \\
\text { INTENSITY }\end{array}$ & $\mathbf{I}$ & II-III & IV & $\mathbf{V}$ & VI & VII & VIII & IX & X+ \\
\hline
\end{tabular}

$\Delta$ Figure 5. The California Integrated Seismic Network (CISN) ShakeMap for the San Simeon mainshock. The red star indicates the epicenter, while the dark line indicates the rupture extent determined by finite fault modeling. The filled triangles show the locations of stations whose ground motions were used to generate the ShakeMap; the open triangles show stations that were not used in the ShakeMap. 


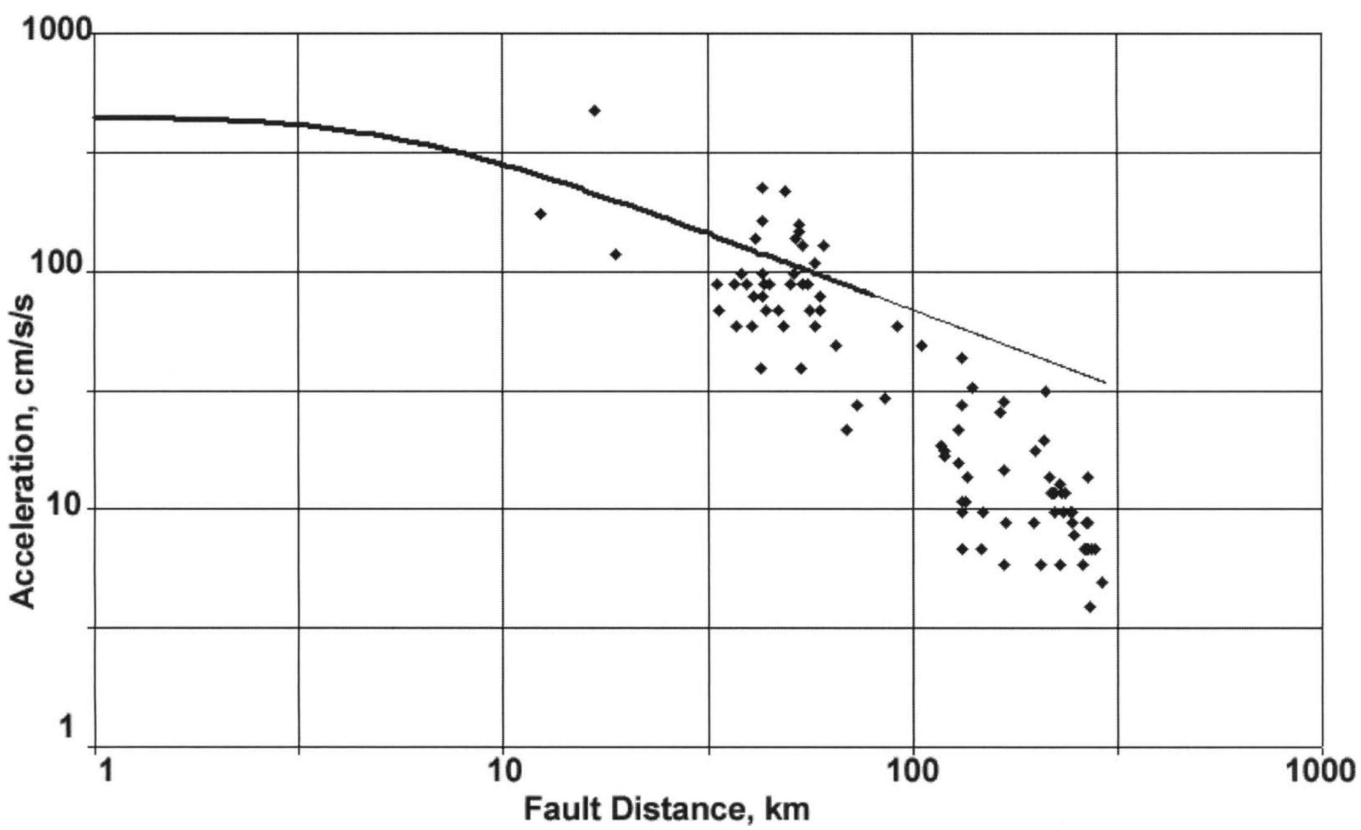

A Figure 6. Variation in peak acceleration data plotted with respect to fault distance. For comparison the Boore-Joyner-Fumal (BJF97) attenuation relationship is shown. The thick line shows the relationship within the $80 \mathrm{~km}$ distance range recommended by the authors; the line is thin beyond. The recorded data demonstrate reasonable agreement with BJF97 in the applicable range, and greater attenuation at larger distances.

$13 \mathrm{~km}$ south of the epicenter, recorded a peak acceleration of $0.18 \mathrm{~g}$, while the instrument at the crest of the San Antonio Dam, $22 \mathrm{~km}$ north-northeast of the epicenter, recorded $0.22 \mathrm{~g}$ (although dam crests are considered structural rather than free-field sites). The largest ground acceleration, $0.48 \mathrm{~g}$, was recorded in Templeton, $38 \mathrm{~km}$ south-southeast of the epicenter but much closer to the southeast end of the aftershock zone and the probable rupture area. The mainshock was also recorded by CSMIP/CISN instruments further to the southeast, in San Luis Obispo $(0.17 \mathrm{~g})$ and Park Hill $(0.15 \mathrm{~g})$, as well as by instruments in Parkfield $(0.03 \mathrm{~g})$, Coalinga $(0.03 \mathrm{~g})$, and Simmler $(0.07 \mathrm{~g})$. The Parkfield Array, operated by CGS, recorded peak accelerations that ranged from $0.04 \mathrm{~g}$ to $0.23 \mathrm{~g}$, very similar to the range observed for the 1983 M 6.5 Coalinga earthquake. The $0.23 \mathrm{~g}$ peak acceleration was recorded at Parkfield Array station C12W, the array station closest to Paso Robles.

A preliminary comparison of the peak acceleration data for this event with those predicted by a standard relationship is useful. A plot of peak acceleration versus distance (log-log) for the records obtained to date is shown in Figure 6. The distances range from $12 \mathrm{~km}$, for the Cambria station, to many stations at distances of more than $250 \mathrm{~km}$. For reference, the Boore-Joyner-Fumal (BJF97, Boore et al., 1997) attenuation relationship is shown. (Coefficients for a reverse fault and an average shallow Vs of $700 \mathrm{~m} / \mathrm{sec}$ were used; the thin line indicates distances beyond the suggested limit of the authors, $80 \mathrm{~km}$.) The data show reasonable agreement with BJF97 in the applicable range. Beyond that, higher attenuation with distance than predicted by the extrapolated BJF97 curve is indicated. These new data, and other recent data from digital instruments, allow extending the existing relationships to greater distances.

The point above the curve at about $15 \mathrm{~km}$ is Templeton, which had $0.48 \mathrm{~g}$, the largest value recorded in the earthquake; higher-than-expected acceleration is consistent with directivity-increased shaking in the rupture direction. The other two closest stations, Cambria and San Antonio Dam, both plot below the curve, consistent with directivityreduced values in the direction away from the rupture.

The absence of stations near the rupture initially limited the accuracy of the automatically produced CISN ShakeMap. When a line-source model for the earthquake became available, the CISN ShakeMap was updated, measuring the distances to sites from the surface projection of the line source. With the line source included, ShakeMap adequately predicted the intensity in the near field, including the MMI 7-8 suffered by Paso Robles and Atascadero. The Templeton and Cambria records were retrieved and incorporated a few hours after the earthquake, further improving the ShakeMap. This highlights the importance of expanding the real-time data collection of strong-motion stations to improve the usefulness of ShakeMap to emergency response.

The nearly unilateral rupture and consequent directivity in the earthquake contributed to the extensive building and chimney damage in Paso Robles and Atascadero. The largest CIIM (Community Internet Intensity Map) intensity reported for the San Simeon earthquake was the MMI 7-8 in Paso Robles, Templeton, and Atascadero. MMI 6 intensities were reported as far south as Santa Maria, and MMI 5-6 


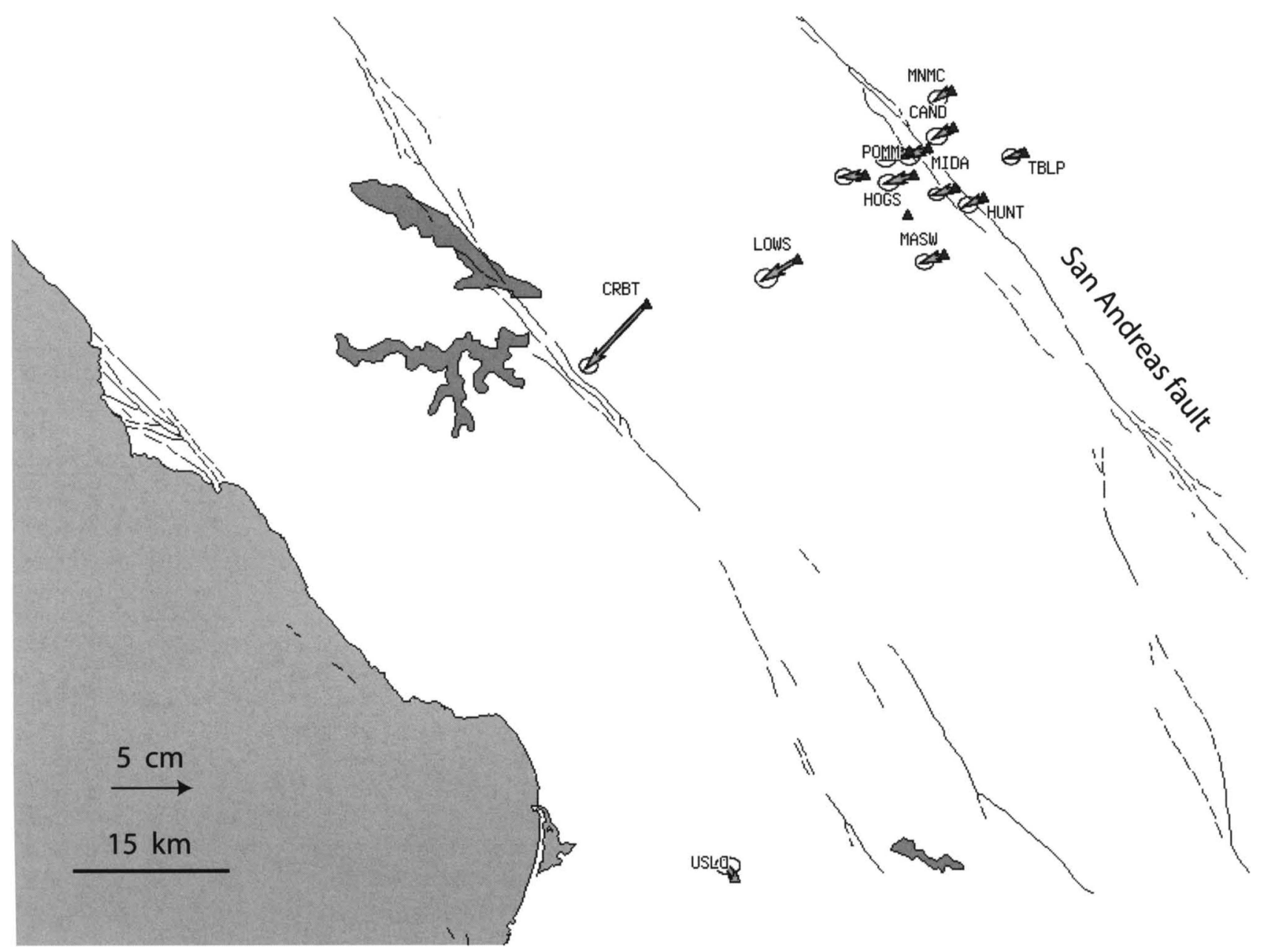

A Figure 7. Static displacements observed at continuously operating GPS stations of the Bay Area Regional Deformation (BARD)/Southern California Integrated GPS Network (SCIGN) array. Station positions before and after the earthquake were differenced to obtain this sampling of ground deformation, that is, permanent shifts that accompanied the earthquake.

intensities in Lompoc and Point Conception, some $100 \mathrm{~km}$ south-southeast of the earthquake. In the opposite direction, however, King City reported only an MMI 5 intensity at a distance of $50 \mathrm{~km}$ from the epicenter. The elongation of the MMI 6 region to the southeast corroborates the conclusion that there was substantial directivity in the mainshock.

\section{GEODETIC OBSERVATIONS}

The earthquake produced measurable static displacements at the fourteen continuously operating Global Positioning System (GPS) stations located closest to the event (Figure 7). All but one of the stations are northeast of the rupture, in the inferred hanging wall, and recorded motion to the southwest. The largest recorded motion, $5.9 \pm 0.3 \mathrm{~cm}$ toward the southwest, was observed at station CRBT (Camp Roberts). The cluster of stations near Parkfield all recorded southwestward movement of approximately $1.5 \pm 0.5 \mathrm{~cm}$. The stations are too far away from the mainshock to constrain a detailed source model. As of one week after the earthquake, no postseismic motion could yet be discerned at CRBT or any of the other nearby stations, nor was there any indication of transient deformation at sites along the San Andreas Fault.

In addition to the coseismic offsets, the GPS stations near Parkfield record at 1-second intervals. Using the method described by Bock et al. (2000), positions of each site relative to the master site, POMM, are estimated at each sample. The positions for the north component are shown in Figure 8. For the site which is closest to the mainshock, CRBT, the peak to peak displacement is $17 \mathrm{~cm}$ and the coseismic displacement is easily seen just after the arrival of the $P$ wave.

\section{GEOLOGIC FIELD OBSERVATIONS}

The San Simeon area was searched both on the ground and by helicopter for signs of surface rupture due to the earthquake. No features that could be ascribed to coseismic surface faulting were found. Almost all the earthquake ground effects that were observed are best ascribed to rockfalls and landslides or to the settlement or slumping of man-made fills. Liquefaction was mapped in the Salinas River channel, in parts of Oceano on the coast, and west of Paso Robles. 


\section{North}

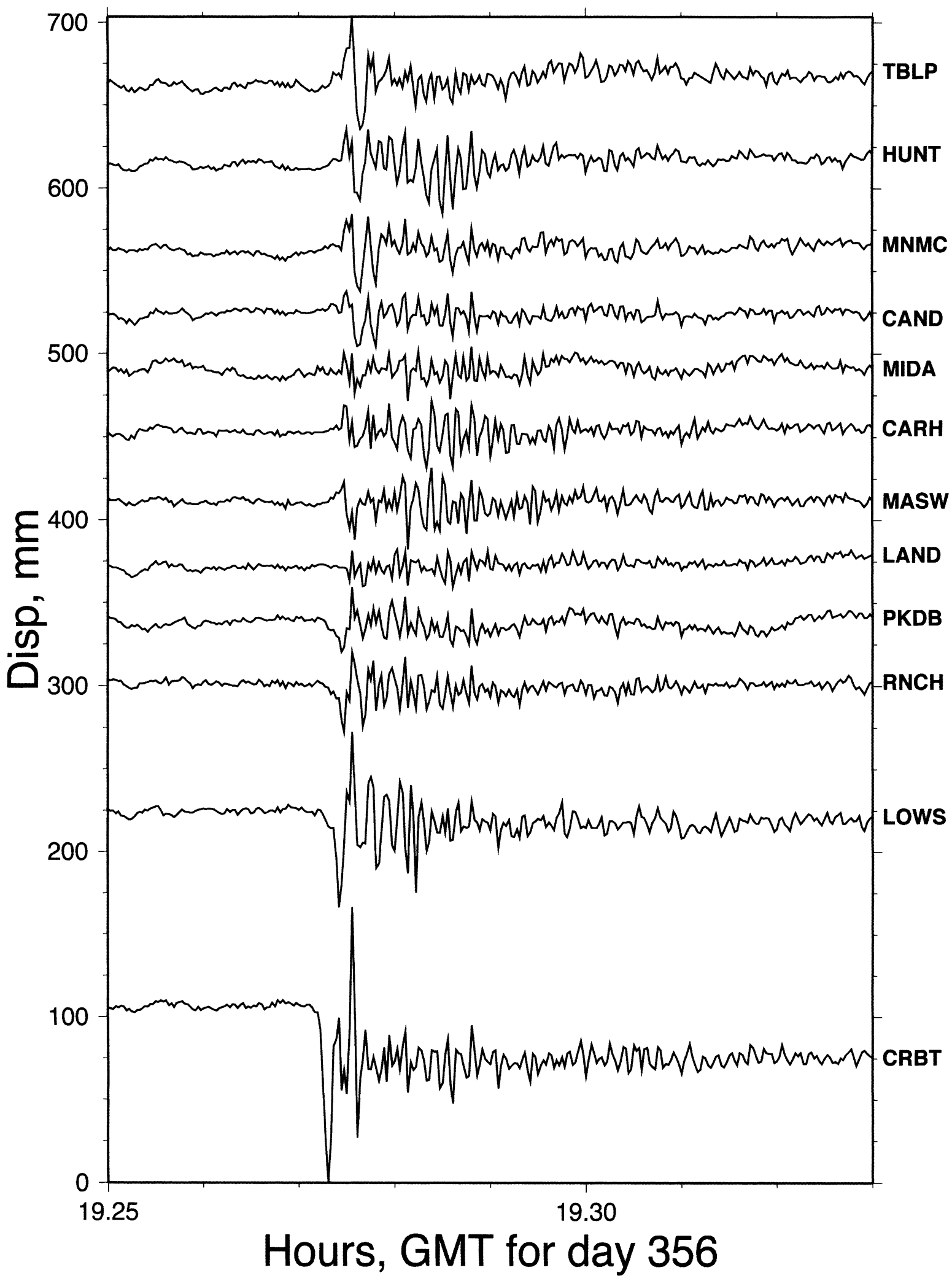

A Figure 8. The San Simeon mainshock recorded at the GPS network at Parkfield, recording at $1 \mathrm{~Hz}$. 
The aerial reconnaissance covered the most probable regions for surface rupture, including a -10 -mile wide zone around the epicenter, the mapped trace of the Oceanic Fault, which approximately corresponds to the upward extension of the northeast-dipping mainshock nodal plane, and the upward extension of the southwest-dipping plane. No features interpretable as surface rupture were observed, although other features such as game trails, cow paths, and fresh erosional rills dating from the last storm were easily seen. Any through-going surface rupture producing greater than $10-15 \mathrm{~cm}$ disturbance of the surface of the earth would likely have been spotted. The absence of tectonic surface rupture implies that the mainshock was a blind thrust event.

The high degree of directivity in energy release in this earthquake was observable in the field. The pattern of landslides, recently snapped-off trees, and severely damaged tile or slate roofs defines a zone extending south-southeast from the epicenter to slightly west of Atascadero. The zone is a few kilometers across and wedge-shaped, widening slightly to the southeast. Outside this apparently high-ground-motion zone, the landslides and rockfalls decrease markedly both in frequency and size. The epicentral area was remarkably undisturbed, with only small rockfalls from roadcuts. The types and distribution of ground failures observed were consistent with experience elsewhere in earthquakes of similar magnitude worldwide.

\section{AFTERSHOCKS}

The San Simeon earthquake produced an energetic aftershock sequence, with more than 1,100 aftershocks above M 1.8, and 165 above M 3, recorded by the CISN in the first week. The majority of the aftershocks occurred to the southeast of the hypocenter, consistent with the rupture directivity. The aftershocks occurred mainly in the hanging wall and exhibit a mix of thrust and strike-slip mechanisms, both accommodating northeast-southwest compression.

The first five days of the aftershock sequence of the San Simeon earthquake were analyzed to determine the statistical characteristics of the sequence. Compared to the generic California aftershock sequence (Reasenberg and Jones, 1989), the rate of aftershocks for this sequence has been slightly higher than average and the decay rate has been slightly slower than average. In the Reasenberg and Jones model of aftershock rate,

$$
r(t)=\frac{10^{(a+b(M m-M c))}}{(t+c)^{p}},
$$

the $a$ value is -1.6 , compared to the median value of -1.76 (meaning the rate is $-50 \%$ higher than average), and the $p$ value is 0.88 , compared to the median value of 1.08 . The $b$ value (0.9) is exactly at the median. Because of the higher productivity and slower decay, the ongoing probability of damaging aftershocks is above the generic values. As usual for aftershock statistics, the probability is concentrated in the region of the mainshock.

The magnitude-frequency distribution of the aftershocks is not completely linear (Figure 9). The nonlinearity is most pronounced between $3 \leq \mathrm{M} \leq 4$ and might be related to the transition from using $M_{L}$ to $M_{w}$ for reported magnitude. It is also notable that the sequence includes twenty aftershocks of $M \geq 4$ but has not yet experienced a $M \geq 5$. The probability of a $M \geq 5$ in the month following 27 December 2003 was still greater than $50 \%$.

The aftershocks were relocated with the double-difference algorithm of Waldhauser and Ellsworth (2000), using phase information from the Northern California Seismic Network (NCSN/CISN), distributed by the Northern California Earthquake Data Center (NCEDC), and the 1D seismic velocity model for the region found by McLaren and Savage (2001). Locations were determined for 783 aftershocks occurring within a week of the mainshock, and 283 background events occurring between 1 January 1985 and 22 December 2003. (To explore these data interactively in 3D, go to http:// www.siovizcenter.ucsd.edu/library/objects/index.html.)

The aftershocks (Figure 2) concentrate in three areas: around and directly to the southeast of the mainshock hypocenter (cross-section $A-A^{\prime}$ ), a cluster elongated in the northsouth direction $-25 \mathrm{~km}$ to the southeast of the mainshock (cross-section B-B'), and a smaller cluster $-15 \mathrm{~km}$ to the southeast of the mainshock (cross-section B- $\mathrm{B}^{\prime}$ ). The lowseismicity gap between the two major clusters approximately corresponds to the peak slip of the mainshock $\sim 15 \mathrm{~km}$ southeast of the hypocenter (Figure 4). The aftershocks in the larger clusters appear to be filling in the area around the main rupture zone of the mainshock.

Although the aftershock sequence does not define a single mainshock fault plane in cross-section, a northeast-dipping plane is suggested. In the region of the mainshock hypocenter, the plane has strike $-295^{\circ}$ and dip $-40^{\circ}$ (Figure 2 , cross-section $\left.A-A^{\prime}\right)$, shallower than the northeast-dipping plane found for the mainshock. Most of the aftershocks occurred in the hanging wall. In the southeast clusters, a plane defined by the base of seismicity has strike $-330^{\circ}$ and $\operatorname{dip}-30^{\circ}$. The more northerly strike for the southeast cluster is also apparent in the seismicity trends in map view. The aftershocks appear largely confined to the hanging wall of a curving or segmented fault plane.

Data from BDSN/CISN were used to find the seismic moment tensor and the best source depth for twelve of the largest $\left(M_{L} \geq 4.0\right)$ aftershocks. These events were all found to be shallow, many of them having the shallowest source depth allowed in the inversion. The moment-tensor solutions are predominantly reverse type with $P$ axes oriented northeast (Figure 10 , black beachballs). Generally, the northwest-striking nodal plane has a relatively steep dip. Many of the solutions for the aftershocks show large non-double-couple components, which may be an artifact due to the events' shallow depths. 


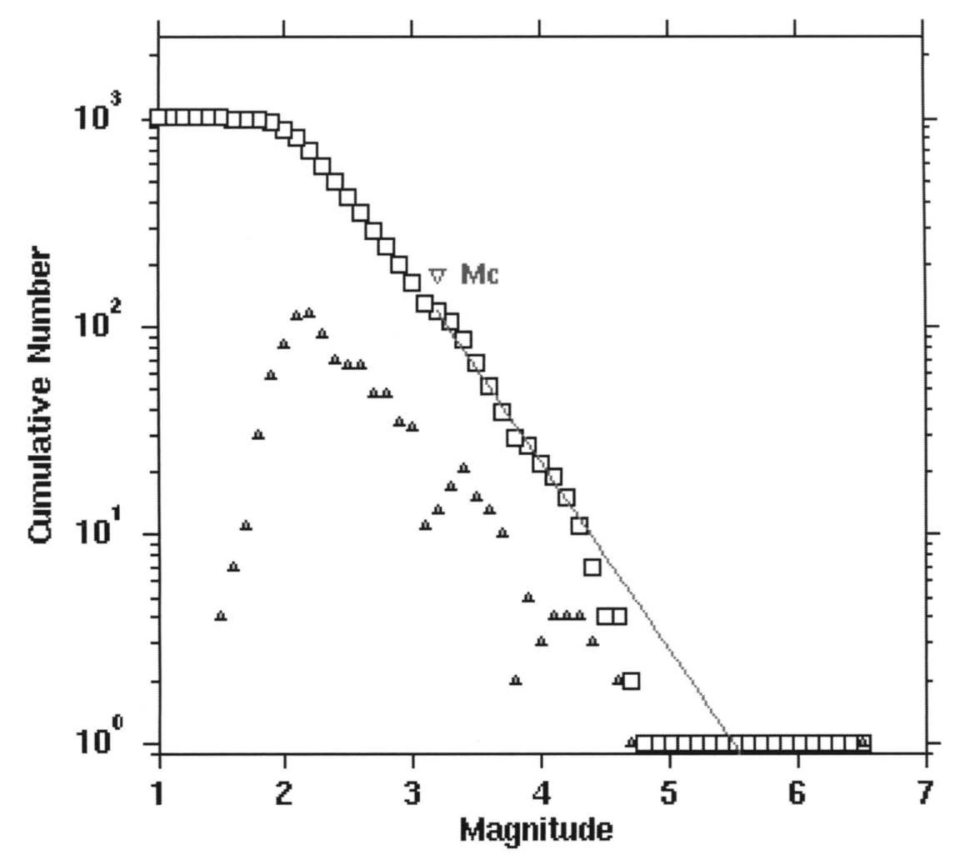

Maximum Likelihood Solution

b-value $=0.902+i-0.08$, a value $=4.96$, a value (annual $)=6.83$

Magnitude of Completeness $=3.2$

$\Delta$ Figure 9. Magnitude-frequency plot for the first five days of aftershocks of the San Simeon earthquake recorded by CISN. Triangles show interval numbers of events, while squares show cumulative numbers (intervals are 0.1 unit of magnitude.) The gray line is the maximum likelihood fit to the cumulative frequency plot, with $M_{c}$ the magnitude of completeness. The zmap tool was used to make this figure (Wiemer and Wyss, 2002).

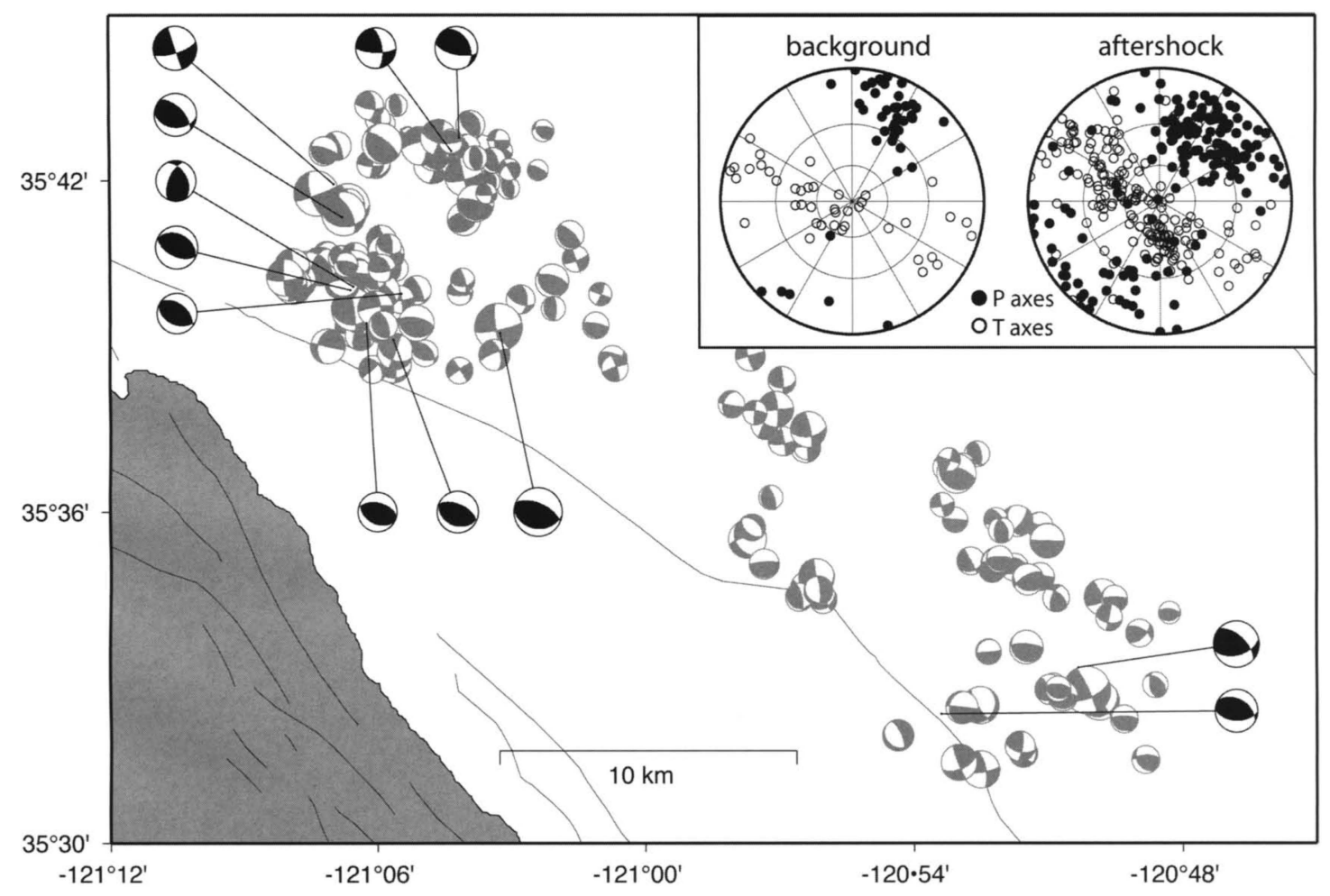

A Figure 10. Fault-plane solutions for aftershocks, from moment-tensor inversion of waveforms (black) and $P$-wave first-motion polarities (gray). Inset shows the $P$ and $T$ axes of the first-motion focal mechanisms for background seismicity (left) and San Simeon aftershocks (right). 
First-motion focal mechanisms were also computed, using phase information from NCSN/CISN (Figure 10, gray beachballs). Take-off angles were recomputed using the double-difference event locations and the seismic velocity model of McLaren and Savage (2001). The technique of Hardebeck and Shearer (2002) identified reasonably good-quality (A-C) focal mechanisms for 174 aftershocks. In addition, firstmotion mechanisms were computed for 41 events prior to the mainshock.

A mix of thrust and strike-slip mechanisms is observed for both aftershocks and background seismicity. Both types of events accommodate northeast-southwest shortening in the hanging wall, with near-horizontal compressional axes trending approximately N30E (Figure 10). Thrust events balance the northeast-southwest shortening with thickening of the crust, while the strike-slip events balance the shortening with northwest-southeast extrusion. Strike-slip aftershocks were also observed in the hanging wall of the M 6.71994 Northridge, California thrust earthquake (Unruh and Hauksson, 1997; Shearer et al., 2003.)

\section{EARTHQUAKE STRESS TRIGGERING}

Earthquakes may be triggered due to changes in static stress, or through dynamic stress changes caused by passing seismic waves. Here we investigate whether the San Simeon earthquake may have been triggered by stress changes and whether it may have triggered other events.

The most recent major earthquake on the nearby segment of the San Andreas Fault, the $1857 M_{w} 7.9 \mathrm{Ft}$. Tejon earthquake, is calculated to have had negligible effect on-or perhaps slightly inhibited - the 2003 San Simeon earthquake (Figure 11A). In contrast, the San Simeon rupture plane was brought about 0.2 bars closer to failure by interseismic stress accumulation on the San Andreas Fault since 1857 (Figure 11B). The San Simeon shock lies within a cluster of $M \geq 5$ shocks during the past half-century; many of them have focal mechanisms similar to that of the 2003 earthquake and might have been promoted by interseismic stress accumulation. This lobe arises from the transition between a fully creeping San Andreas Fault north of Parkfield to a fully locked fault south of Cajon Creek (Figure 11B). The $M_{L} 6.2$ 1952 Bryson shock, in turn, likely changed stress on the San Simeon rupture plane, but the 1952 source is too uncertain to make a reliable calculation. Most of the other central coast $M \geq 5$ shocks appear to occur in regions of increased stress from interseismic stress accumulation since 1857.

Static Coulomb stress changes due to the San Simeon earthquake should have brought parts of nearby faults, including the San Simeon Fault (the northern extension of the Hosgri fault system), the Rinconada Fault, and the San Andreas Fault in the Parkfield region, closer to failure (Figure 12 , top, red areas). There has not been a detectable increase in seismicity rate on these or any other faults in the region, however, aside from the immediate aftershock zone. Although the stress changes are small, $<0.1$ bar on the San Andreas Fault and -1 bar on the San Simeon and Rinconada Faults, stresses on this order are often observed to trigger earthquakes (see review by Harris, 1998).

The only evidence for far-field dynamic triggering is three to five small earthquakes observed at the Geysers geothermal area north of San Francisco during the coda of the San Simeon earthquake. Triggering due to passing seismic waves is often seen at the Geysers area, and the triggering due to San Simeon is relatively weak. Other hydrothermal areas in California, including the Long Valley caldera and the Coso geothermal area, showed no signs of triggered seismicity.

The San Simeon earthquake did trigger hydrological changes in the hard-hit town of Paso Robles. After the earthquake, hot sulfuric water began to flood a parking lot on the site of a former hot spring resort. It was initially thought that the sealed pipes from the former baths had ruptured due to the earthquake, but they were found to be intact. The earthquake must have opened new shallow fractures in the rock, allowing fluids to flow to the surface. The temperature of the water was reported to be $111^{\circ} \mathrm{F}$ and the flow reached approximately 1,000 gallons/minute, comparable to the temperature of $105^{\circ} \mathrm{F}$ and flow of 1,700 gallons/minute when the resort was in use (Waring et al., 1965).

\section{RESPONSE OF THE SAN ANDREAS FAULT AT PARKFIELD}

The San Simeon earthquake occurred $-50 \mathrm{~km}$ west of Parkfield, the most intensively monitored location along the San Andreas Fault. The USGS creepmeter array at Parkfield detected a small amount of right-lateral creep due to the San Simeon event. At most creepmeters, this creep occurred as a step of $<1 \mathrm{~mm}$ at the time of the mainshock, and no further creep activity was observed. The creep at Parkfield may have been shallow slip triggered by the passing seismic waves, or by the permanent stress change of -0.1 bar encouraging rightlateral slip (Figure 12, top, red areas.) The apparent postseismic motions at a few locations are probably due to rainfall.

Changes due to the San Simeon earthquake were also observed at borehole dilatometers in the Parkfield area also operated by USGS (Figure 13). The static strain steps range from $1.75 \mathrm{ppm}$ of dilatation at VC01 (although this may be an instrumental artifact), to $0.08-0.11 \mathrm{ppm}$ of dilatation at DL01 and FR01, to $0.12 \mathrm{ppm}$ of contraction at RH01, and no discernible step at JC01. The observations are qualitatively consistent with the results of the static stress change calculations (Figure 12, bottom), in which VC01, DL01, and FR01 fall within a $>0.03$ microstrain dilatational lobe, while $\mathrm{RH} 01$ is in a $>0.03$ microstrain contractional lobe and JC01 is in $\mathrm{a}<0.03$ microstrain nodal region.

\section{STRUCTURAL ENGINEERING OBSERVATIONS}

Most structural damage during the 22 December 2003 San Simeon earthquake occurred in downtown Paso Robles, located about $39 \mathrm{~km}$ from the epicenter. In addition, local- 
$1857 M=7.9$ coseismic stress changes

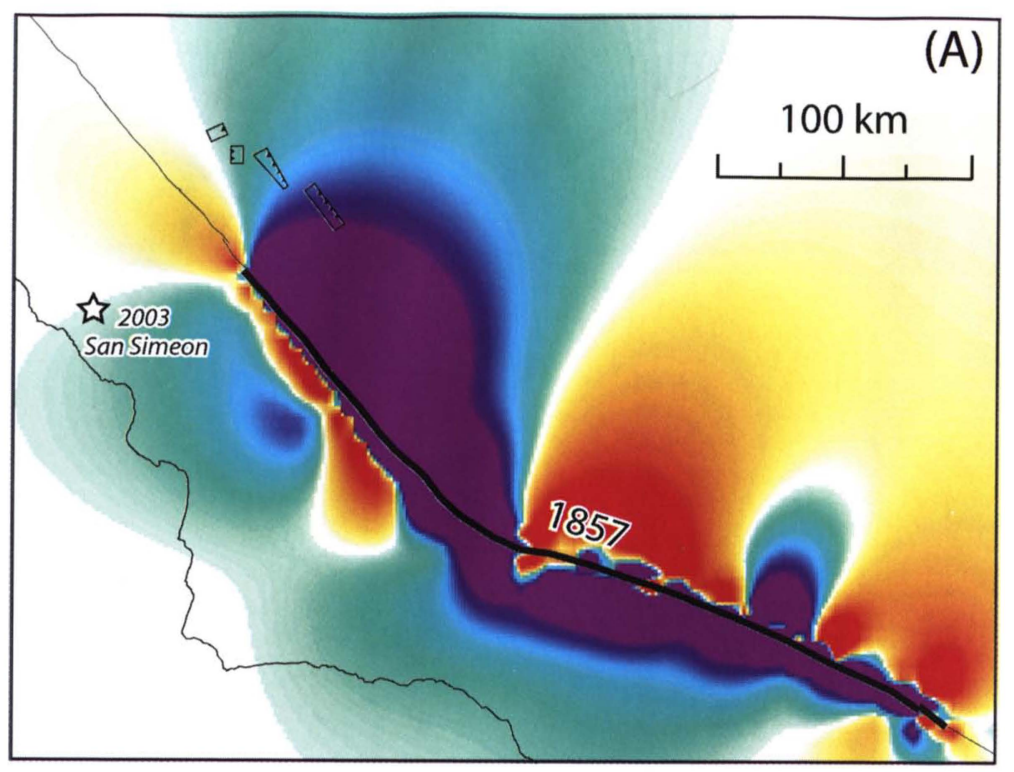

Coulomb stress change, in bars, at $10 \mathrm{~km}$ depth for $\mu=0.4$

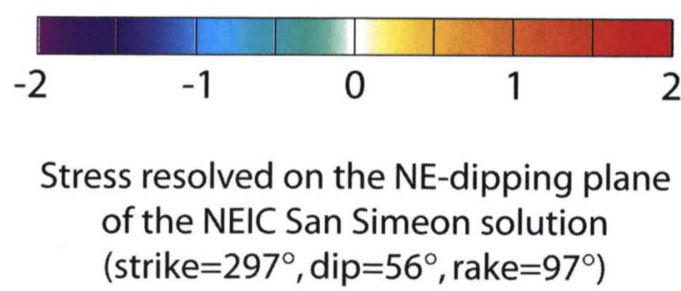

12/28/2003, modified from Lin \& Stein (JGR, 2004)

\section{Interseismic stress accumulation since 1857}
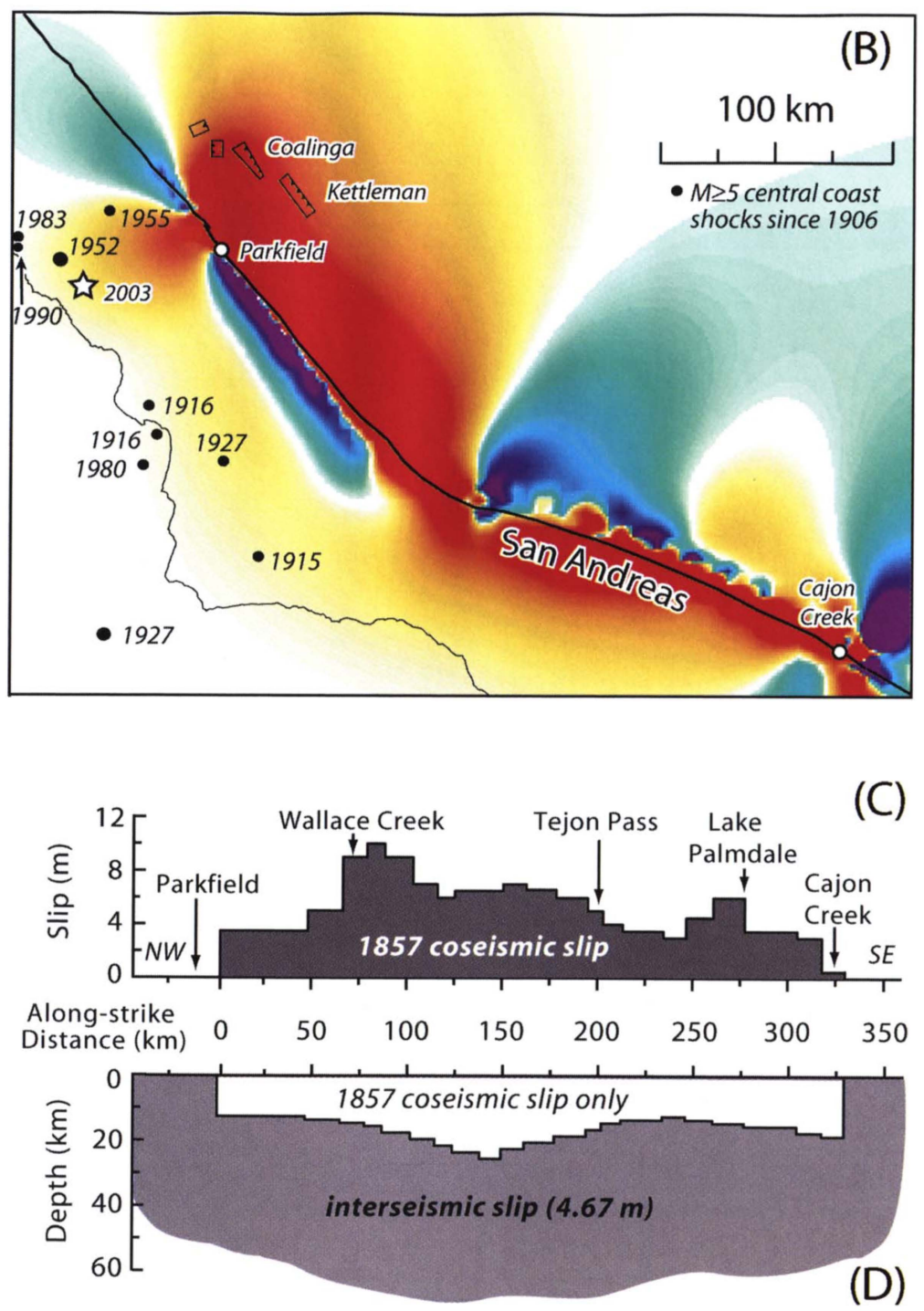

A Figure 11. Coulomb stress imparted to the likely San Simeon earthquake rupture surface by San Andreas Fault slip, modified from Lin and Stein (2004). (A) Coseismic stress transferred by the 1857 $M_{w} 7.9$ Fort Tejon earthquake, resolved onto the 22 December $2003 M_{w} 6.5$ San Simeon rupture plane (NEIC solution; strike $297^{\circ}$, dip $56^{\circ}$, rake $97^{\circ}$ ). The 1857 coseismic slip model is shown in (C). (B) Interseismic stress accumulation during 1857-2003 using the elastic-half-space model shown in (D). Black dots show $\mathrm{M} \geq 5$ earthquakes that have occurred in the central coast area since 1906, from McLaren and Savage (2001), many with focal mechanisms similar to the 2003 quake. (C) Slip model for the 1857 earthquake from Sieh (1978), as modified by subsequent work (Weldon and Sieh, 1985; Salyards et al., 1992; Grant and Sieh, 1993; Grant and Donnellan, 1994). The assumed depth of 1857 faulting is shown in (D), based on the lower depth of current seismicity from Hill (1990). The San Andreas is assumed to be vertical and right-lateral. (D) Interseismic stressing model for the 146-year period between the 1857 Fort Tejon and the 2003 San Simeon events, in which the San Andreas slips at the long-term rate of $3.2 \mathrm{~mm} / \mathrm{yr}$ everywhere except in the 1857 rupture zone. 


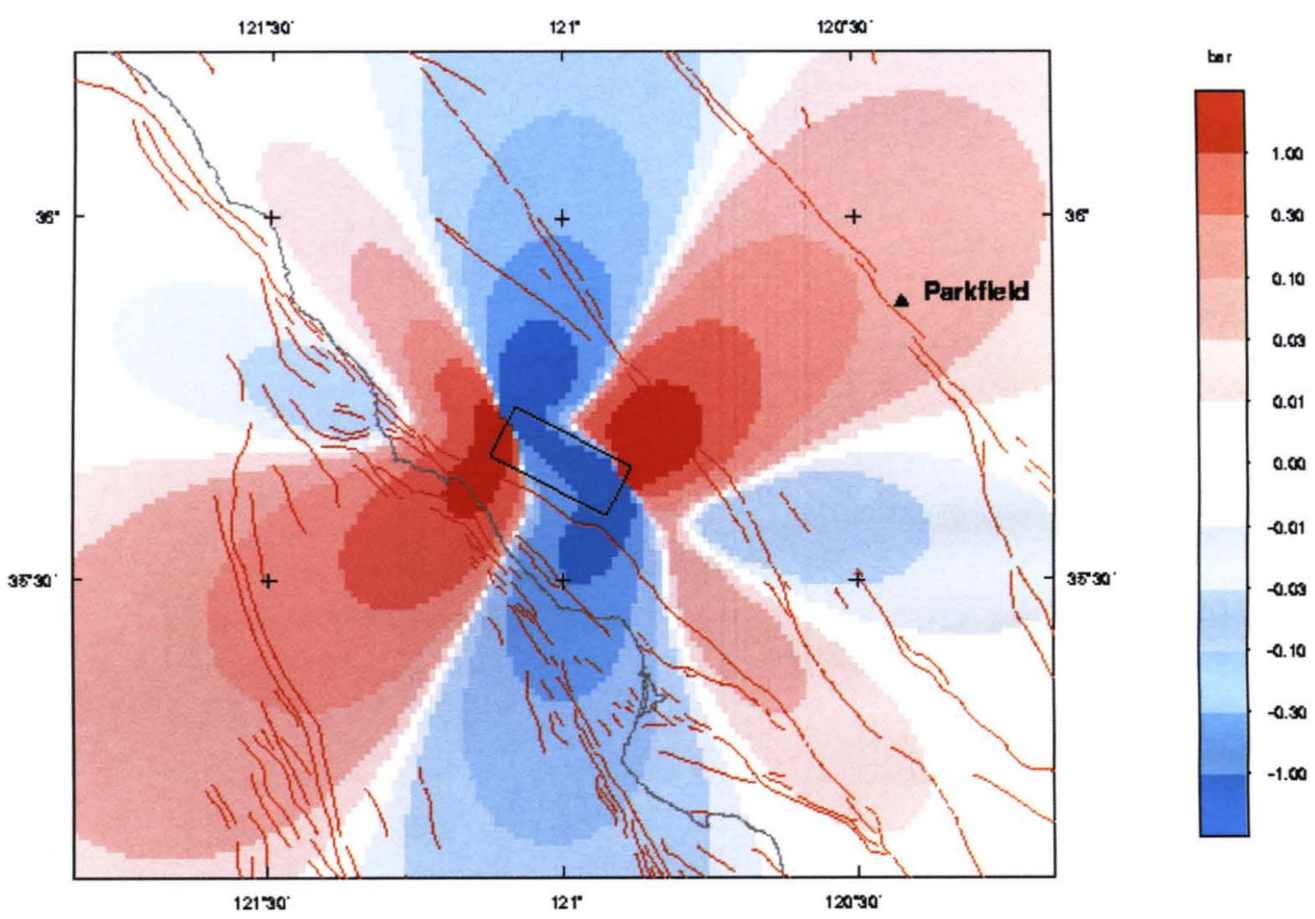

Dllatation (red expanslon; blue contractlon) - Depth=0.1 km

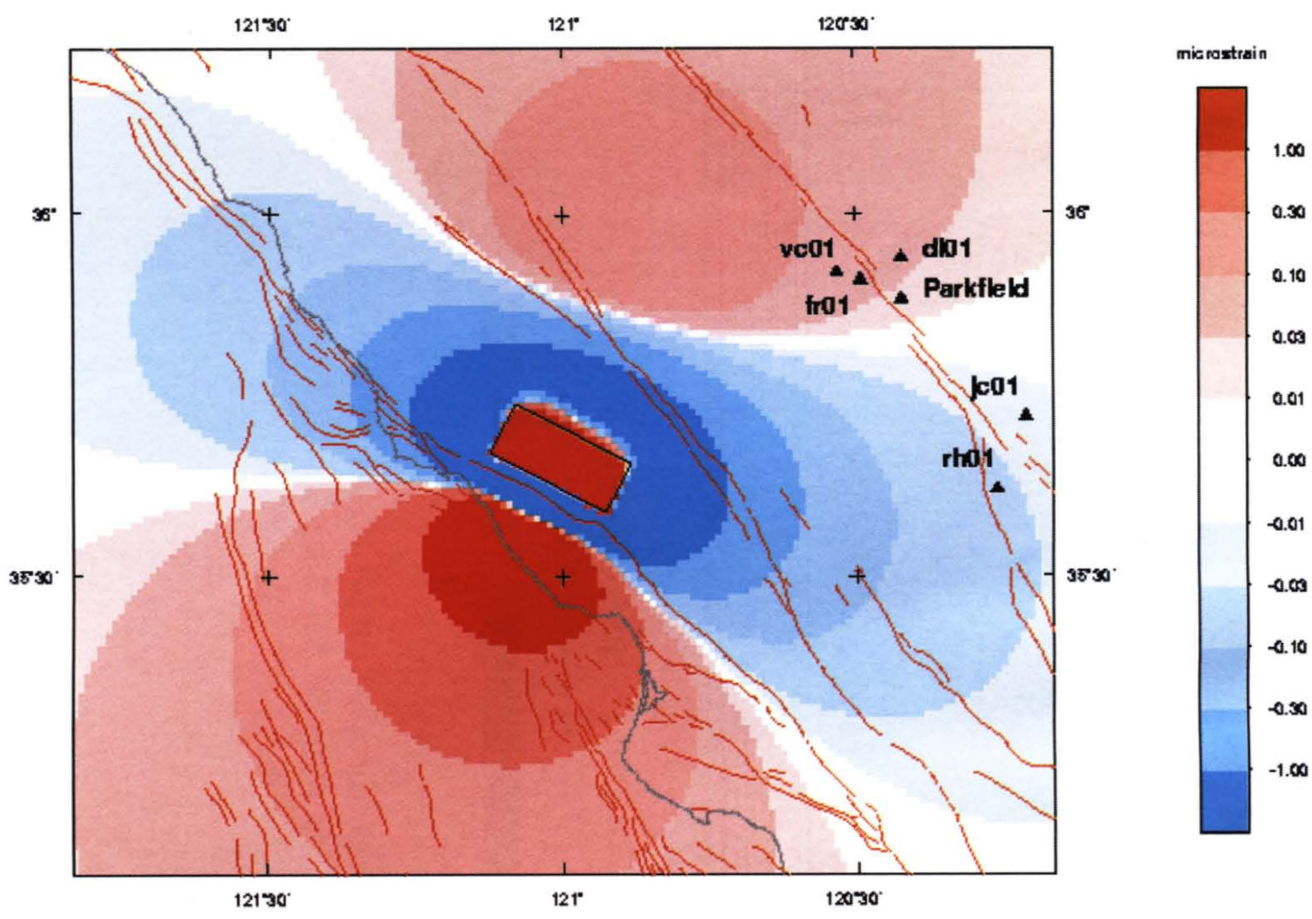

$\Delta$ Figure 12. Static stress changes due to the San Simeon earthquake. The rupture model is $20 \mathrm{~km}$ long, $15 \mathrm{~km}$ wide, and dipping $56^{\circ} \mathrm{E}$, with rake $97^{\circ}$. The northern edge of the plane is aligned with the hypocenter. Top: Coulomb stress change $\triangle \mathrm{CFF}$ on planes striking N40W, dipping $90^{\circ}$, approximately parallel to the SAF in the Parkfield region. Red: Right-lateral strike-slip is encouraged; blue, right-lateral strike-slip is discouraged. Bottom: Dilatational component of strain. Red: expansion; blue, contraction. 


\section{Parkfield Dilatometers}

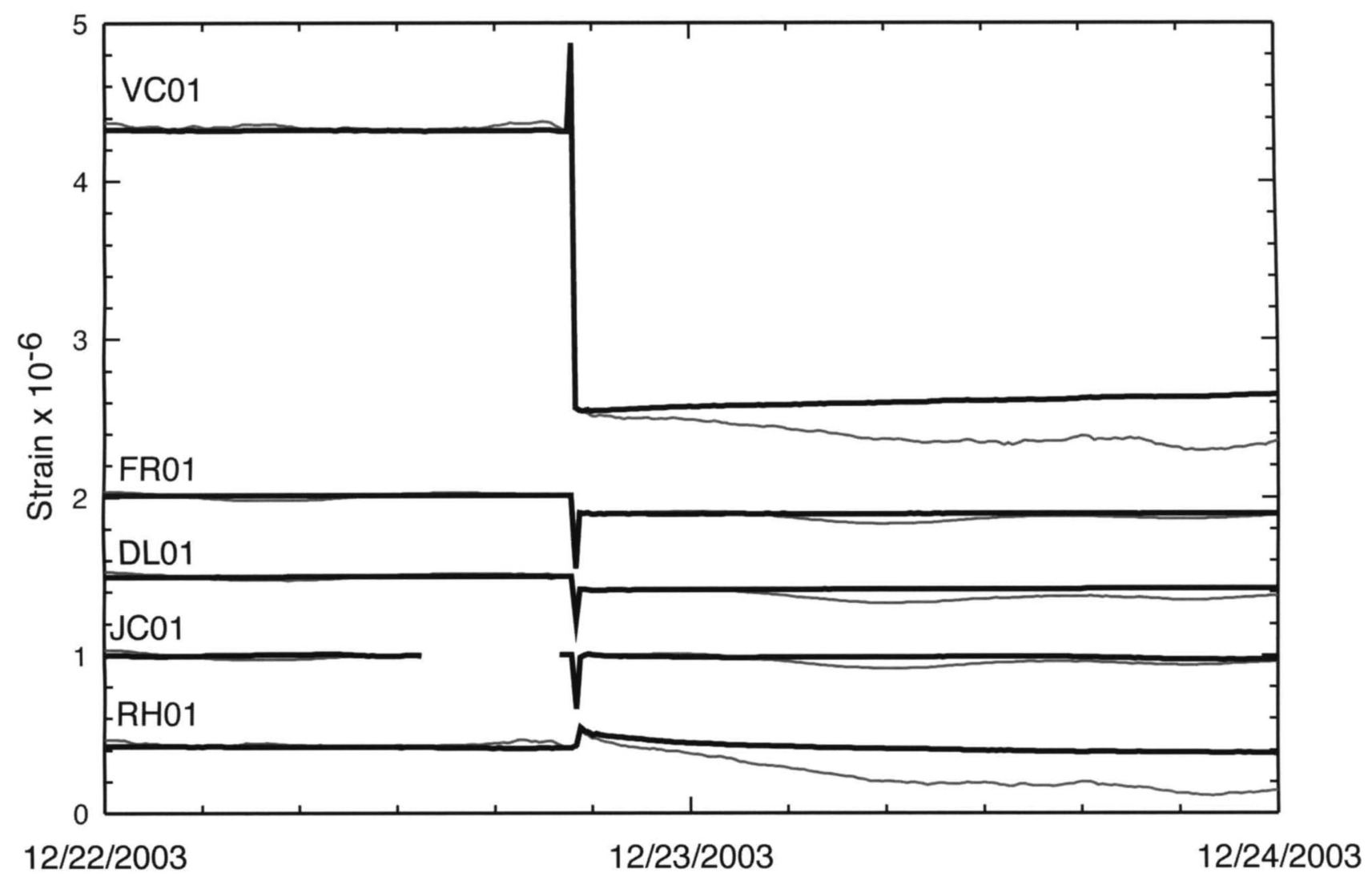

$\Delta$ Figure 13. USGS Parkfield 10-minute dilatometer data. Each record contains one or two points that were sampled during the passage of seismic waves with large dynamic strains; these points are left in. Raw data are shown as a light line, and data with atmospheric pressure and tides removed are shown as a heavier line. Contraction is positive. Times are UT. Station locations shown in Figure 12.

area wineries sustained damage to tasting rooms and production facilities. Summarized here are the overall observations on the structural damage pattern to buildings in downtown Paso Robles and nonstructural damage to local area wineries.

Most buildings in the downtown Paso Robles business district area are very old, some built more than a century ago, constructed of unreinforced masonry (URM). This type of construction is known to be especially vulnerable to earthquakes, and it is not surprising that such buildings suffered extensive damage during the San Simeon earthquake. Most of these buildings were not designed for seismic loads and lacked proper seismic load transfer path. One such building (Acorn building, Figure 14) collapsed, killing two people.

URM buildings that had been seismically retrofitted (Bistro Laurent Building, Figure 14) in general performed much better compared to those that had not been retrofitted; none of the retrofitted buildings collapsed. The basic seismic retrofit scheme included tying the floor diaphragm to the walls (see the bolts in the insert in Figure 14).

In general, buildings on street corners performed poorly compared to other buildings. Configuration of these corner buildings with windows on the street sides and solid walls without openings on the other two sides created plan asym- metry, i.e., large eccentricity between floor center of mass and center of rigidity. The resulting torsional motions during the earthquake shaking imposed much larger demands on lateral load-resisting elements (such as walls) located on street faces of these buildings, compared to buildings with symmetric plans, leading to much larger damage.

URM buildings (even without seismic retrofit) located midblock did not suffer catastrophic failure such as that of the Acorn building, which was located at the end of a block. Most buildings in the affected area are constructed without any gaps between them. It seems that adjacent buildings provided confinement to each other and prevented collapse, except to those buildings sited on the corners. In general, URM parapets and facades were damaged due to out-ofplane motion of both midblock buildings and corner buildings (Ali's Persian Rug building, Figure 14), imposing hazard to adjacent buildings and pedestrians.

Finally, the damage pattern indicates a much stronger shaking in the east-west direction, the direction approximately normal to the fault rupture, as compared to the northsouth direction. This observation is consistent with the observation in previous earthquakes that the shaking may be 

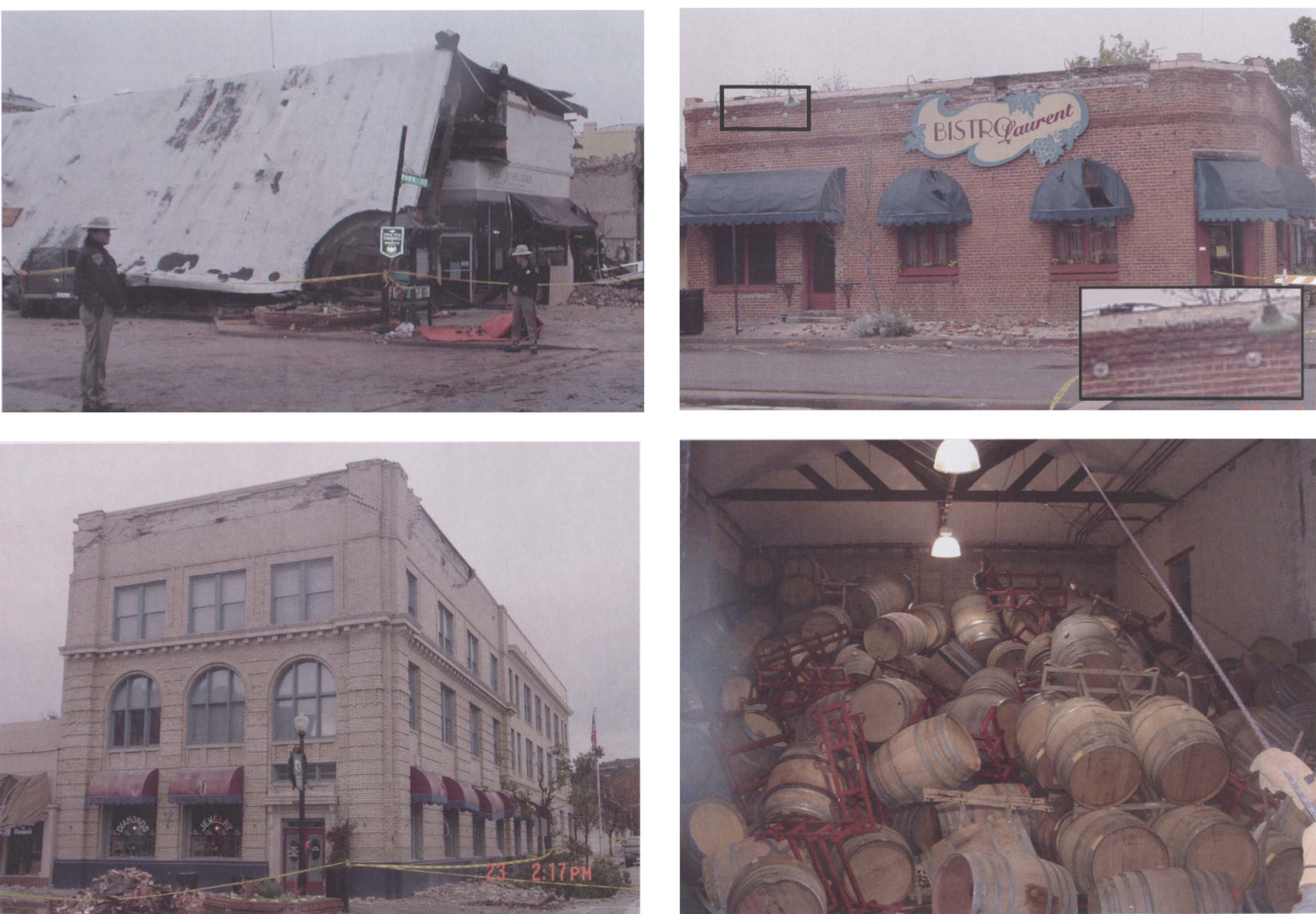

A Figure 14. Upper left: Collapsed Acorn building on the corner of 12th and Park Streets in downtown Paso Robles (photo by Rakesh Goel). Upper right: Bistro Laurent building with seismic retrofit survived the earthquake; inset shows bolts from retrofit (photo by Rakesh Goel and Khalid M. Mosalam). Lower left: Facade damage of Ali's Persian Rug building at the corner of Park and 13th Streets (photo by Khalid M. Mosalam). Lower right: Collapsed wine barrel stacks at Turley Wine Cellars, Highway 46 West, Paso Robles (photo by Josh Marrow). 
strong in the fault-normal direction compared to the faultparallel direction.

Many wineries throughout the region sustained damage to tasting rooms and production facilities. The most severe winery damage was centered along Highway 46, west of the city of Templeton. Nonstructural damage included damaged glasses and bottles of wine in tasting facilities, broken bottles in the valuable wine libraries, ruptured stainless steel wine tanks, and collapse of wine barrels stacked in pyramids and on portable steel racks (Figure 14). Collapsed stacks resulted in rupture of wine barrels and loss of a substantial amount of wine.

No structural damage was observed at any of the wineries in this region. Recovery efforts following the event were fueled by the fact that the wineries are not too busy during the winter months, allowing adequate manpower to clean up the damaged areas. Losses would have been greater and recovery lengthier had the event occurred in the late summer months, during the busy harvest season.

\section{CONCLUSIONS}

The $M_{w} 6.5$ San Simeon earthquake was probably a typical event for the central California coast, a thrust earthquake accommodating a compressional component of PacificNorth America plate motion and incrementally building the mountains that contribute to the beauty of the coast. The mainshock rupture had significant directivity to the southeast, which influenced the pattern of damage and the locations of aftershocks. The aftershock sequence was more vigorous than average, but not greatly so, and the mainshock triggered no more than a half-dozen events outside the immediate aftershock region. The fault structure of the San Simeon region is not well understood, although the mainshock geometry is similar to the main blind thrust of a fault-propagation fold model developed by Namson and Davis (1990). We hope further study of this event will lead to a better understanding of the faults and the earthquake hazards of the central coastal region.

The most significant implication of this event is societal: the importance of retrofitting buildings in earthquake-prone areas. The relatively few lives lost in the San Simeon earthquake can be compared to the more than 30,000 casualties just four days later in the 26 December 2003 M 6.6 Bam earthquake in Iran, mostly due to the collapse of unreinforced masonry buildings. Part of the difference is that the strongest shaking from the San Simeon earthquake probably occurred in the sparsely populated epicentral region, while the fault in the Bam earthquake ran directly through a sizable city. California was also more prepared: Some potentially hazardous buildings in Paso Robles had been retrofitted and performed well in the earthquake. However, there are still many unreinforced masonry buildings in California cities. The tragedies in Paso Robles and in Bam emphasize the importance of retrofitting unreinforced masonry buildings before another earthquake strikes. $\mathbf{k}$

\section{CONTRIBUTORS}

Emily Brodsky, William Ellsworth, Tom Herring, Malcolm Johnston, David K. Keefer, Josh Marrow, Ari Matmon, Andrew Michael, Khalid M. Mosalam, Mark Murray, Thomas Noce, David Oppenheimer, Mitch Pitt, Stephanie Prejean, Mark E. Reid, Lew Rosenberg, Kevin Schmidt, David Schwartz, Tony Shakal, Heidi Stenner, and Steve Walter contributed to the work described in this paper.

\section{ACKNOWLEDGMENTS}

The California Integrated Seismic Network is funded by the USGS internal and external programs, the USGS Advanced National Seismic System, the California Governor's Office of Emergency Services, and the California Geological Survey. We thank the staff of the CISN Northern California Management Center and the NCEDC for their efforts to make rapid reports such as this one possible. We also thank the staff of CGS (CISN Engineering Center) for making strong-motion data available and for dispatching field crews to retrieve strong-motion data and rapid processing on the day of the earthquake. We thank IRIS/DMC for making teleseismic data available in near real-time. We thank Jascha Polet for providing the Caltech/CISN CMT solution for the San Simeon mainshock, and Colin Williams for information about the Paso Robles hot springs. John Filson of USGS and Tim McCrink, Jerry Treimann, and Bill Bryant of CGS assisted with geological investigations. The following people assisted with the BARD/SCIGN GPS vectors: Duncan Agnew, Yehuda Bock, John Galetzka, Ken Hurst, Nancy King, Jessica Murray, Doug Neuhauser, Jerry Svarc, Chris Walls, Frank Webb. We thank Gary Fuis, Andrew Michael, and William Ellsworth for helpful reviews of the manuscript. We thank Debi Kilb at the SIO Visualization Center for making the aftershock data available in $3 \mathrm{D}$ online.

\section{REFERENCES}

Bassin, C., G. Laske, and G. Masters (2000). The current limits of resolution for surface value tomography in North America, Eos, Transactions of the American Geophysical Union 81, F897.

Bock, Y, R. Nikolaidis, P. J. Jonge, and M. Bevis (2000). Instantaneous geodetic positions at medium distance with the Global Positioning System, Journal of Geophysical Research 105, 28,223-28,254.

Boore, D. M., W. B. Joyner, and T. E. Fumal (1997). Equations for estimating horizontal response spectra and peak acceleration from western North American earthquakes: A summary of recent work, Seismological Research Letters 68, 128-153.

Dreger, D. S. and A. Kaverina (2000). Seismic remote sensing for the earthquake source process and near-source strong shaking: A case study of the October 16, 1999 Hector Mine earthquake, Geophysical Research Letters 27, 1,941-1,944.

Grant, L. B. and A. Donnellan (1994). 1855 and 1991 surveys of the San Andreas Fault; Implications for fault mechanics, Bulletin of the Seismological Society of America 84, 241-246.

Grant, L. B. and K. E. Sieh (1993). Stratigraphic evidence for seven meters of dextral slip on the San Andreas Fault during the 1857 
earthquake in the Carrizo Plain, Bulletin of the Seismological Society of America 83, 619-635.

Hardebeck, J. L. and P. M. Shearer (2002). A new method for determining first-motion focal mechanisms, Bulletin of the Seismological Society of America 92, 2,264-2,276.

Harris, Ruth A. (1998). Introduction to special section: Stress triggers, stress shadows, and implications for seismic hazard, Journal of Geophysical Research 103, 24,347-24,358.

Hartzell, S. H. and T. H. Heaton (1983). Inversion of strong ground motion and teleseismic waveform data for the fault rupture history of the 1979 Imperial Valley, California, earthquake, Bulletin of the Seismological Society of America 73, 1,553-1,583.

Hill, D. P., J. P. Eaton, and L. M. Jones (1990). Seismicity, 1980-1986, in R. E. Wallace (editor), The San Andreas Fault System, California, U.S. Geological Survey, 115-151.

Jennings, C. W. (1975). Fault Map of California with Locations of Volcanoes, Thermal Springs, and Thermal Wells, Geologic Data Map, California Division of Mines and Geology, no. 1.

Ji, C., D. J. Wald, and D. V. Helmberger (2002) Source description of the 1999 Hector Mine, California, earthquake, Part I: Wavelet domain inversion theory and resolution analysis, Bulletin of the Seismological Society of America, 92, 1,192-1,207.

Lin, J. and R. S. Stein (2004). Stress triggering in thrust and subduction earthquakes, and stress interaction between the southern San Andreas and nearby thrust and strike-slip faults, Journal of Geophysical Research 109, B02303 doi:10.1029/2003JB002607.

McLaren, M. and W. U. Savage (2001). Seismicity of south-central coastal California: October 1987 through January 1997, Bulletin of the Seismological Society of America 91, 1,629-1,658.

Namson, J. and Davis, T. L. (1990) Late Cenozoic fold and thrust belt in the southern Coast Ranges and Santa Maria basin, California, American Association of Petroleum Geologists Bulletin 74, 467-492.

Reasenberg, P. A. and Lucile M. Jones (1989). Earthquake hazard after a mainshock in California, Science 243, 1,173-1,176.

Salyards, S. L., K. E. Sieh, and J. L. Kirschvink (1992). Paleomagnetic measurement of nonbrittle nonseismic deformation across the San Andreas Fault at Pallett Creek, Journal of Geophysical Research 97, $12,457-12,470$.

Shearer, P. M., J. L. Hardebeck, L. Astiz, and K. B. Richards-Dinger (2003). Analysis of similar event clusters in aftershocks of the 1994 Northridge, California, earthquake, Journal of Geophysical Research 108, B1, doi:10.1029/2001JB000685.

Sieh, K. E. (1978). Slip along the San Andreas Fault associated with the great 1957 earthquake, Bulletin of the Seismological Society of America 68, 1,421-1,448.

Unruh, J. R., R. J. Twiss, and E. Hauksson (1997). Kinematics of postseismic relaxation from aftershock focal mechanisms of the 1994 Northridge, California, earthquake, Journal of Geophysical Research 102, 24,589-24,603.

Waldhauser, F. and W. L. Ellsworth (2000). A double-difference earthquake location algorithm: Method and application to the northern Hayward Fault, California, Bulletin of the Seismological Society of America 90, 1,353-1,368.
Waring, G. A., R. R. Blankenship, and R. Bentall (1965). Thermal Springs of the United States and Other Countries of the World: A Summary, U.S. Geological Survey Professional Paper 492.

Weldon, R. J., II and K. E. Sieh (1985). Holocene rate of slip and tentative recurrence interval for large earthquakes on the San Andreas Fault in Cajon Pass, southern California, Geological Society of America Bulletin 96, 793-812.

Wiemer, S. and M. Wyss (2002). Mapping spatial variability of the frequency-magnitude distribution of earthquakes, Advances in Geophysics 45, 259-302.
Jeanne Hardebeck

U.S. Geological Survey

345 Middlefield Road MS977

Menlo Park, CA 94025

jhardebeck@usgs.gov

(J.H., J.B., J.L., R.S., R.S., J.C.T.)

University of California Berkeley, California

(D.D.)

California Polytechnic State University San Luis Obispo, California

(R.G.)

California Geological Survey

Sacramento, California

(V.G.)

U.S. Geological Survey

Pasadena, California

(K.H., L.J., K.S.)

California Institute of Technology

Pasadena, California

(C.J.)

Woods Hole Oceanographic Institution Woods Hole, Massachusetts

(J.L.)

U.S. Geological Survey Vancouver, Washington

(E.R.) 